\title{
Urgences
}

\section{Ah ! la belle Hélène...}

\section{Monique Dumais}

Numéro 15, octobre 1986

Épigraphiques

URI : https://id.erudit.org/iderudit/025289ar

DOI : https://doi.org/10.7202/025289ar

Aller au sommaire du numéro

Éditeur(s)

Urgences

ISSN

0226-9554 (imprimé)

1927-3924 (numérique)

Découvrir la revue

Citer ce document

Dumais, M. (1986). Ah ! la belle Hélène... Urgences, (15), 21-21.

https://doi.org/10.7202/025289ar

Ce document est protégé par la loi sur le droit d'auteur. L'utilisation des services d'Érudit (y compris la reproduction) est assujettie à sa politique d'utilisation que vous pouvez consulter en ligne.

https://apropos.erudit.org/fr/usagers/politique-dutilisation/
Cet article est diffusé et préservé par Érudit.

Érudit est un consortium interuniversitaire sans but lucratif composé de l’Université de Montréal, l'Université Laval et l'Université du Québec à Montréal. Il a pour mission la promotion et la valorisation de la recherche. https://www.erudit.org/fr/ 


\section{Monique Dumais}

Tous les dangers que nous rencontrons à chaque voyage vers les sources.

Hélène Cixous: Viure l'orange

Ah! la belle Hélène, que de voyages faudra-t-il faire pour rencontrer les sources!

Vois les âges qu'il a fallu traverser sans aucun recours que nous-mêmes.

Anges ou sourcières, rentrons toutes les dents pour vivre nos soucis sans perdre haleine.

Sourdes ou ivres, nous allons vers les voies sages qui s'ouvrent à nous.

Hé! là, vivre l'or trouvé au fond des sources. 